\title{
JEZYK WSPÓŁCZESNEJ PEDAGOGIKI W PERSPEKTYWIE KOMPARATYSTYKI MYŚLI PEDAGOGICZNEJ. WYBRANE PRZYKEADY ZMIAN LEKSYKALNYCH
}

\begin{abstract}
Streszczenie: Artykuł dotyczy zmian, jakie dokonały i dokonują się w zakresie podstawowych pojęć pedagogicznych, w okresie od 1989 roku, czyli od rozpoczęcia transformacji społeczno-ustrojowej do dnia dzisiejszego. Analizy zawarte w tekście skoncentrowane zostały na konsekwencjach, jakie niesie zjawisko zmiany języka dla uprawiania pedagogiki, jej tożsamości i statusu jako dyscypliny naukowej. Szczególną wagę przywiązuję przy tym do języka rozumianego jako zbiór symboli, którym posługują się badacze zainteresowani wybranym fragmentem rzeczywistości. Aby zobrazować wyżej wskazane procesy zastosowałam kryterium leksykalno-semantyczne, odnoszące się do zasobów języka współczesnej pedagogiki i znaczeń, podstawowych dla niej kategorii badawczych. Tekst rozpoczynają uwagi dotyczące języka oraz pojęć, jako językowych reprezentacji określonego fragmentu rzeczywistości społecznej, w tym przypadku edukacyjnej. Następnie zwracam uwagę na te kategorie pojęciowe, które bezpośrednio dotyczą przedmiotu badań współczesnej pedagogiki oraz jego właściwości. Na tej podstawie wskazuję wybrane przykłady procesów urzeczywistniających tę zmianę, a dalej konsekwencje, jakie moim zdaniem niesie ona dla uprawiania współczesnej pedagogiki.
\end{abstract}

Słowa kluczowe: język pedagogiki, komparatystyka myśli pedagogicznej, podstawowe pojęcia pedagogiczne.

Prezentowane rozważania dotyczą języka współczesnej polskiej pedagogiki, a dokładniej, najważniejszych dla tego języka kategorii pojęciowych. Treść artykułu zogniskowana została na zmianach, jakie dokonały i/lub dokonują się w tym zakresie od 1989 roku, czyli od rozpoczęcia transformacji społeczno-ustrojowej oraz na tym, jakie konsekwencje niesie to zjawisko dla uprawiania pedagogiki, jej tożsamości i statusu jako dyscypliny naukowej. Wyżej zasygnalizowane rozważania odnoszą się do szeroko rozumianej myśli pedagogicznej, którą za Bogusławem Śliwerskim rozumiem jako przynależną do świata humanistyki ${ }^{1}$, w obrębie którego znajdują

$1 \mathrm{Za} \mathrm{A}$. Kucnerem humanistykę szeroko rozumianą odnoszę do całokształtu ludzkiego poznania, istnienia oraz działania i rozumiem ją jako sumę ludzkich wytworów wraz z ich immanentnym 
się przedmioty badań humanistycznych (Śliwerski 2009, s. 42-44). Taki właśnie świat myśli pedagogicznej istnieje potencjalnie w słowach, jako ich znaczenia językowe, ma więc byt niezależny od losów ludzi, którzy je w swoich myślach wytworzyli. Tę perspektywę analiz opieram na takim rozumieniu nauki, które określa ją jako kulturowo uregulowaną praktykę badawczą (Kotowa 1996, s. 15-29), będącą równocześnie praktyką społeczną, ciągle na nowo - co potwierdza teoria Thomasa S. Kuhna (Kuhn 2009) - dokonującą wglądu we własną tożsamość oraz poszukującą systemów teoretyczno-konceptualnych i narzędzi badawczych. Ten epistemologiczno-metodologiczny aspekt jest szczególnie znaczący w perspektywie obrazu rzeczywistości, jaki powstaje dzięki uprawianiu współczesnych badań humanistyczno-społecznych. Szczególną wagę przywiązuję przy tym do języka jako zbioru symboli, systemu znaków, którym posługują się badacze zainteresowani wybranym fragmentem rzeczywistości, w tym przypadku edukacją szeroko rozumianą i uwarunkowaniami dyskursu edukacyjnego (Milerski, Śliwerski 200o, s. 144). A skoro język (jako dziedzina kultury) jest jednocześnie narzędziem myśli, to odwołanie się do tego narzędzia jest już określonym sposobem funkcjonowania w przestrzeni symbolicznej, w tym w praktyce badawczej. Język jest tym fenomenem, który wyraża treść naszych stanów mentalnych, pozwala się komunikować, odzwierciedla rzeczywistość i umożliwia jej lepsze poznanie, a jak podkreślają współcześni językoznawcy, kognitywiści czy filozofowie, język jest przede wszystkim narzędziem wspólnego działania w świecie, jego główną funkcją jest koordynacja i ujednolicanie naszego poznania i działania (Brożek 2016, s. 85-105). Język pedagogiki osadzony w tej perspektywie odnosi się do tekstu, który pozostaje w określonej relacji, uwikłany jest w kontekst dyskursu, który reprezentuje ${ }^{2}$. Tekst jako taki „konstytuuje swoje znaczenia (czy też inspiruje do ustanawiania znaczeń) w polu wielu krzyżujących się odniesień: do wiedzy, doświadczenia użytkownika, jego osobowości; do innych tekstów; ale także w kontekście społecznym, historycznym, kulturowym. [...] To bycie "pomiędzy» tekstu, jako cecha konstytutywna wyznaczająca jego ontyczność, uzasadnia komparatystyczne badanie tekstu rozumiane jako aktywność interpretacyjna wykazywana w procesie zestawiania, konfrontowania przekazów, dyskursów, mediów; w akcie wychodzenia poza tekst, jego kontekstualizacji i rekontekstualizacji, przekraczania granic istniejących i juz nazwanych" (Szczęsna 2017, s. 5-6). Ta wielość kontekstów jest swoistym ramowaniem tekstu, które okazuje się konieczną czynnością interpretacyjną uczestniczącą w ustanawianiu znaczeń i tworzeniu się kultury.

znaczeniem. Jako taka skupia się ona na odkrywaniu i artykułowaniu znaczenia w odniesieniu do wytworów człowieka w kontekście jego dziejowego, społecznego i kulturowego sposobu bycia. Przyjmuję, że humanistyka symbolizuje całokształt myślenia i działania, które obrazuje złożoną sytuację człowieka w świecie (zob. Kucner 2006, s. 9-20).

2 Zob. analizy dotyczące języka współczesnej pedagogiki oraz językowego obrazu rzeczywistości edukacyjnej (Hejnicka-Bezwińska 2008, s. 258-302). 
Aby zobrazować wyżej wskazane procesy, zastosowałam kryterium leksykalno-semantyczne ${ }^{3}$, odnoszące się do zmian, jakie dokonały/dokonują się w zakresie zasobów języka pedagogiki i znaczeń podstawowych dla niej kategorii pojęciowych. Przy tym pragnę podkreślić, iż komparatystyczny wymiar przeprowadzonych analiz to badania wybranego aspektu myśli pedagogicznej, dotyczące rozumienia wieloznaczności terminów pedagogicznych i zmian z tym związanych. Zakładam przy tym, że jeśli myśl zostaje wyrażona w słowach, to treść tej myśli zostaje ujęta w znaczeniach tych słów (zob. Śliwerski 2009, s. 42-44). W tym przypadku przedmiotem badań są znaczenia wybranych podstawowych pojęć pedagogicznych oraz procesy zmian zachodzące $w$ języku pedagogiki. W takim rozumieniu komparatystyczne badania myśli pedagogicznej służą poszerzaniu i rozwijaniu teoretycznej wiedzy o edukacji, w tym tworzeniu i rekonstruowaniu teorii pedagogicznych ${ }^{4}$.

W tym kontekście pojęcia są konstruktami, które odzwierciedlają uzgodnione znaczenie przypisane terminom. Pojęcia jako charakterystyczne dla danego tekstu posiadają określone znaczenia, są kategoriami teoretycznymi (analitycznymi), ale są równocześnie językową reprezentacją określonego fragmentu rzeczywistości społecznej, w tym edukacyjnej, a to rozumienie ma szczególną wagę dla pedagogiki jako nauki empirycznej, ze względu na konstytutywny dla niej związek teorii $\mathrm{z}$ praktyką ${ }^{5}$. Przestrzeń edukacyjną interpretuję przy tym zarówno w wymiarze fizycznym, jak i symbolicznym oraz przyjmuję, że pedagogika, jak wszystkie nauki empiryczne, może budować swoje teorie, czyli poznawcze i symboliczne reprezentacje własnego przedmiotu badań. Stąd poniższe rozważania skoncentrowane zostały na tych kategoriach pojęciowych, które dotyczą przedmiotu badań współczesnej pedagogiki oraz jego właściwości ${ }^{6} \mathrm{i}$ jako takie funkcjonują w pedagogicznych tekstach naukowych. Pragnę przy tym podkreślić, że odnosząc się do poszczególnych pojęć i związanych $\mathrm{z}$ ich funkcjonowaniem procesów, przyjmuję perspektywę opisową, a nie wartościującą, a odwołując się do typologii zaproponowanej przez Bogusława Bieszczada, przyjmuję, że zarówno perspektywa wertykalna, jak i horyzontalna dopełniają ogląd języka pedagogiki (Bieszczad 2013, s.123-127), przy czym własne rozważania odnoszę do wybranych pojęć funkcjonujących w języku nauki. Pragnę przy tym podkreślić, że język naukowy pedagogiki, w interpretacji

3 Przyjmując powyższe kryterium, zakładam, że „leksykalny” znaczy odnoszący się do słownictwa, a semantyka to dział językoznawstwa, którego przedmiotem jest analiza znaczeń wyrazów i jako taka interpretowana być może jako teoria relacji zachodzących między językiem danej teorii a dziedziną tej teorii. Zob. Słownik Języka Polskiego. (2007). Warszawa: Wydawnictwo Naukowe PWN.

4 Zob. rodzaje i cele badań porównawczych wg M. Myszkowskiej-Litwy (2010, s. 308-318).

5 Por. powiązanie przedmiotu badań pedagogiki z jego językową reprezentacją (Gnitecki 1999, s. 272).

6 Zob. zmiany leksykalne w określaniu przedmiotu polskiej pedagogiki współczesnej (Hejnicka-Bezwińska 2006, s. 86-89). 
np. Stanisława Palki, to podstawowy element zagadnień z dziedziny pedagogiki ogólnej (Palka 1995, s. 9-20).

Stawiam przy tym tezę mówiącą, że rozumienie najważniejszych dla pedagogiki pojęć (zwłaszcza dotyczących jej przedmiotu badań) stanowi fundament myślenia pedagogicznego, gdyż jak podkreśla B. Śliwerski, „definiowanie pojęć w humanistyce, gdzie o jednoznaczność jest niezwykle trudno, nie tylko sprzyja pogłębionej dyskusji, ale także pozwala opanować myślą różnorodność zjawisk przez łączenie ich w grupy wedle najogólniejszych kategorii" (Śliwerski 2009, s. 26).

W tym kontekście formułuję następujące dwa pytania: 1) Jakie zmiany dokonały/ dokonują się w tym zakresie w języku polskiej pedagogiki po 1989 roku? i 2) Jakie konsekwencje niosą one dla uprawiania pedagogiki, a szczególnie dla teorii jako praktyki pedagogicznego myślenia?

Biorąc pod uwagę to, że zmiana myślenia rozpoczyna się od języka, pragnę wskazać na wybrane przykłady zjawisk urzeczywistniających tę zmianę, czyli procesów, które moim zdaniem wnoszą nową perspektywę interpretacyjną. Przy czym warto pokreślić, że myślenie, zmieniając perspektywę naszego rozumienia rzeczywistości, przekształca nas samych działających w tej przestrzeni, także w przestrzeni pedagogicznej (Folkierska 1993). Treść i przedmiot poniższych rozważań sytuuję w świecie nr 3, według koncepcji Karla R. Poppera, świecie, który wypełniają przede wszystkim systemy teoretyczne czy też inaczej, przedmioty myśli.

Przyjmując powyższe założenia oraz uwzględniając postawione pytania, pragnę zwrócić uwagę na następujące procesy ${ }^{7}$ :

- rekonstruowanie znaczeń, zmiana rozumienia podstawowych pojęć pedagogicznych. Przykładem może tu być rozumienie i dominacja pojęcia „wychowanie” w języku pedagogiki naukowo-socjalistycznej (zob. Rutkowiak 1996, s. 13-29), a po 1989 roku nadawanie nowych znaczeń tak podstawowym pojęciom, jak edukacja, wychowanie, kształcenie. Egzemplifikacją efektów tego procesu jest model dziesięciościanu edukacji, zaproponowany przez Zbigniewa Kwiecińskiego (Kwieciński 1996, s. 31-38) czy też typologia zaproponowana przez Teresę Hejnicką-Bezwińską, która rozpatrując edukację jako proces całościowy, ujmowany holistycznie, wyróżnia trzy grupy szczegółowych procesów edukacyjnych: edukacyjne procesy naturalnego rozwoju

7 Zawarte w artykule wybrane przykłady procesów odnoszą się do tekstów pedagogicznych funkcjonujących we współczesnym dyskursie edukacyjnym, opublikowanych po 1989 roku. Pragnę przy tym podkreślić, że nie są to efekty badań porównawczych teorii wychowania (por. Śliwerski 1998), ale analizy języka naukowego tego dyskursu. Odwołując się do teorii Kristena B. Madsena, przyjęłam perspektywę metateoretyczną, która zakłada, że teorie to złożone systemy składające się ze słów i zdań, stąd metateoria zajmuje się m.in. słownictwem (pojęcia) i językiem (teorie) nauki (zob. Madsen 1980). Zbieżne stanowisko w tym zakresie prezentuje także Friedrich W. Kron, kiedy opisuje przyjęte przez siebie podstawy naukowo-teoretyczne badań, dotyczące m.in. funkcji teorii naukowej jako metateorii (Kron 2012, s. 258-262). 
człowieka, edukacyjne procesy uspołecznienia jednostki oraz edukacyjne procesy celowościowe (Hejnicka-Bezwińska 2008, s. 36-38);

- zmiana relacji istniejących między pojęciami, w tym zmiana zakresów znaczeniowych poszczególnych pojęć. Na przykład relacja istniejąca między nauczaniem a uczeniem się, a w konsekwencji interpretacja „uczenia się” jako centralnej kategoria pojęciowej współczesnej praktyki edukacyjnej (Hejnicka-Bezwińska 2008, s. 125-165);

- pojawianie się w języku współczesnej pedagogiki nowych pojęć, wynikające ze zmian paradygmatycznych, zwrotów badawczych i rozwoju innych nauk, głównie humanistyczno-społecznych, ale także ekonomicznych oraz w wyniku zmian dziejących się w rzeczywistości społeczno-kulturowej, w tym edukacyjnej. Przykładem w tym przypadku mogą być takie pojęcia, jak: edukacja alternatywna (zob. Śliwerski 1992; 1995; 2001). Inny jako uczestnik procesów edukacyjnych (zob. Chrzanowska i in. 2013), lider oświaty (zob. Madalińska-Michalak 2015), wolny rynek edukacyjny, usługi edukacyjne (zob. Potulicka, Rutkowiak 2010). Przy czym, jak podkreśla B. Bieszczad, pamiętać należy, że „złożoność sytuacji edukacyjnych wymusza do ich adekwatnego ujęcia stosowanie różnych języków i zróżnicowanych perspektyw interpretacyjnych, które niekoniecznie mają status paradygmatycznej przemiany" (Bieszczad 2013, s. 104). Jednocześnie, jego zdaniem, tzw. „mocne” zwroty badawcze wprowadzają zasadnicze zmiany do języka danej dyscypliny i pozwalają reinterpretować wizję badanej rzeczywistości (zob. Kowalewski, Piasek 2010); - zasilanie języka pedagogiki pojęciami o charakterze ogólnohumanistycznym, a zatem wzrost znaczenia takich kategorii badawczych, jak np.: ambiwalencja, autonomia, dyskurs, emancypacja, opór, podmiot, podmiotowość. Zastosowanie powyższych pojęć zmieniło perspektywę oglądu edukacji jako praktyki społeczno-kulturowej oraz pozwoliło wskazać relacje i właściwości dla niej konstytutywne. Przykładem mogą tu być prace Lecha Witkowskiego, dotyczące kategorii ambiwalencji (Witkowski 1994, s. 189-199) lub Marii Czerepaniak-Walczak, dotyczące emancypacyjnej teorii edukacji (Czerepaniak-Walczak 2006);

- metaforyzacja języka pedagogiki. Dzięki temu procesowi można w tekście ująć to, czego nie da się wyartykułować wprost, w oryginalnej perspektywie teoretycznej dotyczy to nawet klasycznych zagadnień pedagogicznych, a metafora staje się wówczas intelektualnym narzędziem, które pozwala pogłębiać i rozszerzać rozumienie rzeczywistości edukacyjnej. Odwołanie się do metafory i refleksyjnego nad nią namysłu zmienia dotychczasowe schematy znaczeniowe oraz poszerza pulę interdyscyplinarnych kontekstów. Doskonałym przykładem są w tym przypadku prace badawcze realizowane przez Marię Dudzikową (Dudzikowa 2016);

- pewne pojęcia z czasem umierają, często na skutek zmian paradygmatycznych, światopoglądowych, ideologicznych czy ustrojowych. I tak np. we 
współczesnej myśli pedagogicznej pojęcie technologii wychowania zmieniło swój status, a kategoria zachowania ustępuje miejsca działaniu, jako aktywności podmiotowej, odniesionej do sprawstwa uczestników procesów edukacyjnych (zob. Michalak 2003; Kowalczuk-Walendziak 2012);

- zmiany dokonujące się w języku pedagogiki pokazują także znaczenie społecznych źródeł czy też uwarunkowań stosowanych przez pedagogów pojęć. Przykładem mogą być ideologiczne uzasadnienia dla stosowania wybranych pojęć, które zagościły w zinstytucjonalizowanej nauce oraz najnowszych konceptualizacjach rzeczywistości (także edukacyjnej), np. edukator, ekonomizacja działalności edukacyjnej (zob. Rutkowiak 2010, s. 229-247).

Odpowiadając na pytanie dotyczące tego, jakie konsekwencje niosą powyższe procesy dla uprawiania pedagogiki, a szczególnie dla teorii jako praktyki pedagogicznego myślenia, pragnę wskazać następujące ustalenia:

- skoro język (jako zbiór symboli) to narzędzie myśli, to zastosowanie określonego narzędzia (pojęcia) czy też jego (re)definicja wywołują zmianę myślenia na temat rzeczywistości, którą symbolizują. W związku z tym mamy do czynienia zarówno z ciągłością, jak i ze zmianą pedagogicznego myślenia w tym zakresie. Ciągłość wyraża się w tym, że odwołujemy się do puli podstawowych/klasycznych pojęć pedagogicznych, a zmiana wyraża się w tym, że nadajemy im inne znaczenia, rekonstruujemy relacje między nimi;

- pedagogika rekonstruując rozumienie podstawowych kategorii pojęciowych, dookreśla procesualnie swoją tożsamość. Na zasadzie spirali wraca do punktu wyjścia (do podstawowych pojęć określających jej przedmiot badań), ale równocześnie wkracza na wyższy poziom, ponieważ jako dyscyplina rekonstruuje swój dorobek;

- temu zjawisku towarzyszy zmiana myślenia o przedmiocie badań pedagogiki, o jej tożsamości i miejscu wśród innych nauk humanistyczno-społecznych. Pojawiają się bowiem nowe obiekty/przedmioty lub aspekty badań pedagogicznych;

- następuje zmiana myślenia o rzeczywistości edukacyjnej, także w zakresie ontologii, epistemologii i metodologii badań edukacyjnych/pedagogicznych, pojawiają się nowe paradygmaty badań i praktyki badawcze, a w ich efekcie, nowe teorie pedagogiczne, gdyż jak podkreślał Janusz Gnitecki, zmiana pojęć generuje zmianę w zakresie struktury teorii pedagogicznych (zob. Gnitecki 2006);

- pojawiają się nowe mapy pojęć pedagogicznych, nowa kartografia myśli. $\mathrm{Na}$ znaczeniu zyskuje kategoryzacja jako praktyka bezpośrednio związana z rozumieniem świata. Przy czym język (jako żywy fenomen) wpływa na kategoryzację zdarzeń, faktów, procesów. Wkład kategoryzacji do rozumienia rzeczywistości społeczno-kulturowej, w tym edukacyjnej, wyraża się m.in. w tym, że jest ona pewnym uporządkowaniem pola przedmiotowego 
oraz w tym, że zakłada ona pewną wiedzę o porządkowanej dziedzinie. Klasycznym przykładem mogą tu być „pulsujące kategorie” jako wyznaczniki mapy odmian myślenia o edukacji, w interpretacji Joanny Rutkowiak (Rutkowiak 1995, s.13-50);

- biorąc pod uwagę relację istniejącą między myśleniem a działaniem pedagogicznym, kluczowe (także dla praktyki pedagogicznej) staje się rozumienie pojęć (wynikające z myślenia), nadawanie znaczeń, które urzeczywistnia się w szerokim horyzoncie rozumienia świata. Przykładem rozważań wzmacniających tę perspektywę są analizy przeprowadzone przez Rafała Godonia, w których wskazuje on na argumenty przeciwko dychotomii myślenia i działania (Godoń 2012, s. 42-58), wzmacniając równocześnie zwrotny, zapośredniczający ruch między nimi. Dzięki takiemu ujęciu teoria pedagogiczna, za sprawą włączania działania w swoje pole problemowe, jest bliska życiu, doświadczeniu działania;

- w tym kontekście wzrasta znaczenie uprawiania hermeneutyki jako sztuki rozumienia różnych głosów, języków pedagogiki. Mamy bowiem do czynienia z wielością interpretacji rzeczywistości i postaci wiedzy ją opisujących;

- zmiana dokonująca się w języku (w zakresie rozumienia podstawowych pojęć) ma także charakter formacyjny, dotyczący tożsamości pedagogów, zarówno teoretyków, badaczy, jak i praktyków. Stąd także pojawiają się nowe pola badawcze oraz nowe subdyscypliny i dziedziny wiedzy pedagogicznej, zogniskowane wokół nowych lub rekonstruowanych kategorii, np. pedagogika rodzaju, pedagogika twórczości, pedagogika inkluzyjna (zob. Śliwerski 2010);

- język pedagogiki ma takie cechy, jak rzeczywistość społeczno-kulturowa, w której powstaje. Cechuje go wielość, różnorodność i wieloznaczność (Tuchańska 2016, s. 99-121) dotycząca także rozumienia podstawowych pojęć pedagogicznych.

\section{Konkluzja}

Na koniec pragnę podkreślić, że wyżej zasygnalizowane zmiany związane są z kształtowaniem intelektualnych narzędzi i komunikacyjnych więzi, bez których trudno byłoby mówić o rozwoju nauki i o rozwoju pedagogicznego myślenia. Język bowiem pełni niezastąpioną rolę w naszych wysiłkach poznawczych, „będąc rusztowaniem, pozwalającym na obiektywizację i instytucjonalizację zmagań, które człowiek prowadzi ze światem" (Brożek 2016, s. 70), także ze światem pedagogicznym. W tym rozumieniu jest on elementem „formacji intelektualnej” ", która

8 Za Barbarą Skargą przyjmuję, że formacja intelektualna jest wielowarstwową strukturą twierdzeń ontologicznych, epistemologicznych i aksjologicznych, ujawniających się w języku, schematach percepcji, akceptowanych modelach badań, związkach nauki z praktyką społeczną. W zakresie każdej formacji intelektualnej B. Skarga wyróżnia cztery jej warstwy. Składają się na nie: 
ciągle na nowo stanowi o tożsamości pedagogiki i jej miejscu wśród innych nauk humanistyczno-społecznych. Wobec powyższych ustaleń procesy zmian dziejące się w języku współczesnej pedagogiki zyskują szczególne znaczenie, zwłaszcza dla teorii jako praktyki pedagogicznego myślenia.

\section{Bibliografia}

Bieszczad B. (2013). Pedagogika i język. Perspektywa ponowoczesna. Kraków: Wydawnictwo Uniwersytetu Jagiellońskiego.

Brożek B. (2016). Myślenie. Podręcznik użytkownika. Kraków: Copernicus Center Press Sp. Z. o.o.

Chrzanowska I., Jachimczak B., Pawelczak B. (red.). (2013). Miejsce Innego we współczesnych naukach o wychowaniu. W poszukiwaniu pozytywów. Poznań: Wydawnictwo Naukowe UAM.

Czerepaniak-Walczak M. (2006). Pedagogika emancypacyjna. Rozwój świadomości krytycznej człowieka. Gdańsk: GWP.

Dudzikowa M. (2016). Wstępnie o metaforze (także militarnej). W: Dudzikowa M., Jaskulska S. (red.). Twierdza. Szkoła w metaforze militarnej. Co w zamian? T. 1. Warszawa: Wydawnictwo Wolters Kluwer.

Folkierska A. (1993). Glosa do tekstu Christopha Wulfa „Paradygmaty nauki o wychowaniu. Powstanie nauki o wychowaniu w Niemczech”. „Kwartalnik Pedagogiczny", 4.

Gnitecki J. (1999). Zarys pedagogiki ogólnej. Gorzów Wielkopolski: Wojewódzki Ośrodek Metodyczny.

Gnitecki J. (2006). Struktura teorii pedagogicznej. Poznań: Wydawnictwo Naukowe PTP Oddział w Poznaniu.

Godoń R. (2012). Między myśleniem a działaniem. O ewolucji anglosaskiej filozofii edukacji. Warszawa: Wydawnictwa Uniwersytetu Warszawskiego.

Hejnicka-Bezwińska T. (2006). Konsekwencje badawcze wynikające z uznania dyskursów edukacyjnych przedmiotem pedagogiki. W: Kubinowski D., Nowak M. (red.). Metodologia pedagogiki zorientowanej humanistycznie. Kraków: Oficyna Wydawnicza „Impuls”.

Hejnicka-Bezwińska T. (2008). Pedagogika ogólna. Warszawa: Wydawnictwa Akademickie i Profesjonalne.

Kotowa B. (1996). Epistemologiczna waloryzacja poznania. W: Such J. i in. (red.). Rozważania o poznaniu naukowym. Poznań: Wydawnictwo Fundacji Humaniora.

Kowalczuk-Walędziak M. (2012). Poczucie sprawstwa społecznego pedagogów. Kraków: Oficyna Wydawnicza „Impuls”.

problematyka, aparatura pojęciowa oraz system reguł i pole znaczeń, w zasięgu których porusza się myśl (zob. Skarga 1987). 
Kowalewski J., Piasek W. (red.). (2010). Zwroty badawcze w humanistyce. Olsztyn: Instytut Filozofii Uniwersytetu Warmińsko-Mazurskiego w Olsztynie.

Kron F. W. (2012). Pedagogika. Kluczowe zagadnienia. Pojęcia. Procesy. Modele. Sopot: GWP.

Kucner A. (2006). Transcendentny oraz immanentny sens humanistyki jako nauki. W: Kowalewski J., Piasek W., Śliwa M. (red.). Granice dyscyplin-Arne w Humanistyce. Olsztyn: Instytut Filozofii Uniwersytetu WarmińskoMazurskiego w Olsztynie.

Kuhn T. S. (2009). Struktura rewolucji naukowych. Warszawa: Fundacja Aletheia.

Kwieciński Z. (1996). Dziesięciościan edukacji (składniki i aspekty - potrzeba całościowego ujęcia). W: Jaworska T., Leppert R. (red.). Wprowadzenie do pedagogiki. Wybór tekstów. Kraków: Oficyna Wydawnicza „Impuls”.

Madalińska-Michalak J. (2015). Dyrektor szkoły liderem - inspiracje i perspektywy. Warszawa: Wolters Kluwer.

Madsen K. B. (1980). Współczesne teorie motywacji. Naukoznawcza analiza porównawcza. Warszawa: PWN.

Michalak J.M. (2003). Poczucie odpowiedzialności zawodowej nauczycieli. Studium teoretyczno-empiryczne. Warszawa: Wydawnictwo Instytutu Badań Edukacyjnych.

Milerski B., Śliwerski B. (red.). (200o). Pedagogika. Leksykon PWN. Warszawa: Wydawnictwo Naukowe PWN.

Palka S. (1995). Aktualne sposoby uprawiania pedagogiki ogólnej w Polsce. W: Hejnicka-Bezwińska T. (red.). Pedagogika ogólna. Tradycja-TeraźniejszośćNowe wyzwania. Bydgoszcz: Wydawnictwo Uczelniane Wyższej Szkoły Pedagogicznej.

Potulicka E., Rutkowiak J. (2010). Neoliberalne uwikłania edukacji. Kraków: Oficyna Wydawnicza „Impuls”.

Rutkowiak J. (2010). Nauczyciel w dramacie wartości wychowawczych. Problem na pograniczu pedeutologii i ekonomii. W: Potulicka E., Rutkowiak J. Neoliberalne uwikłania edukacji. Kraków: Oficyna Wydawnicza „Impuls”.

Rutkowiak J. (1995). „Pulsujące kategorie” jako wyznaczniki mapy odmian myślenia o edukacji. W: Rutkowiak J. (red.). Odmiany myślenia o edukacji. Kraków: Oficyna Wydawnicza „Impuls”.

Rutkowiak J. (1996). Wielość języków pedagogiki a problem jej tożsamości. W: Jaworska T., Leppert R. (red.). Wprowadzenie do pedagogiki. Wybór tekstów. Kraków: Oficyna Wydawnicza „Impuls”.

Skarga B. (1987). Przeszłość i interpretacje. Warszawa: Państwowe Wydawnictwo Naukowe.

Szczęsna E., Kubiński P., Leszczyński M. (red.). (2017). Między dyskursami, sztukami, mediami. Komparatystyka jutra. Kraków: UNIVERSITAS. 
Szczęsna E. (2017). Wprowadzenie. W: Szczęsna E., Kubiński P., Leszczyński M. (red.). Między dyskursami, sztukami, mediami. Komparatystyka jutra. Kraków: UNIVERSITAS.

Śliwerski B. (red.). (1992). Edukacja alternatywna - dylematy teorii i praktyki. Kraków: Oficyna Wydawnicza „Impuls”.

Śliwerski, B. (red.). (2001). Nowe konteksty (dla) edukacji alternatywnej XXI wieku. Kraków: Oficyna Wydawnicza „Impuls”.

Śliwerski B. (red.). (1995). Pedagogika alternatywna - dylematy teorii. Kraków: Oficyna Wydawnicza „Impuls”.

Śliwerski B. (red.). (2010). Pedagogika. Subdyscypliny i dziedziny wiedzy o edukacji. T. 4. Gdańsk: GWP.

Śliwerski B. (2009). Współczesna myśl pedagogiczna. Znaczenia, klasyfikacje, badania. Kraków: Oficyna Wydawnicza „Impuls”.

Śliwerski B. (1998). Wspótczesne teorie i nurty wychowania. Kraków: Oficyna Wydawnicza „Impuls”.

Tuchańska B. (2016). Codzienność w nauce ponowoczesnej. „Nauka”, 2, s. 99-121. Witkowski L. (1994). Ambiwalencja jako kategoria dla socjologii edukacji.

W: Brzeziński J., Witkowski L. (red.). Edukacja wobec zmiany społecznej. Poznań-Toruń: Wydawnictwo Edytor.

\title{
LANGUAGE OF CONTEMPORARY PEDAGOGIC IN PERSPECTIVE OF COMPARATIVE OF THE EDUCATIONAL THOUGHT. SELECTED EXAMPLES OF LEXICAL CHANGES
}

\begin{abstract}
The article concerns the changes that have been made and are being made in the field of basic pedagogical concepts, in the period from 1989, that is from the beginning of the socio-political transformation, to the present day. The analyses included in the text focused on the consequences of the change of language for pedagogy, its identity and status as a scientific discipline. I place a special emphasis on the language understood as a collection of symbols used by researchers interested in a selected fragment of reality. To illustrate the above-mentioned processes, I applied the lexical and semantic criterion referring to the resources of the contemporary language of pedagogy and meanings, its basic research categories. The texts begin with remarks about language and concepts as a linguistic representation of a specific fragment of social reality, in this case of education. Then, I pay attention to those conceptual categories that directly concern the subject of research in contemporary pedagogy and its properties. On this basis, I point to the selected examples of processes that implement this change, and then the consequences that, in my opinion, it brings to the practice of contemporary pedagogy.
\end{abstract}

Key words: language of pedagogy, comparative aspect of pedagogical thought, basic pedagogical concepts. 
Alina Wróbel - dr hab. nauk społecznych w dyscyplinie pedagogika, prof. nadzwyczajny Uniwersytetu Łódzkiego. Pracuje na Wydziale Nauk o Wychowaniu, w Katedrze Teorii Wychowania, w Zakładzie Teorii Kształcenia i Wychowania. Zainteresowania naukowo-badawcze: pogranicze pedagogiki ogólnej i teorii wychowania; filozoficzne i teoretyczne podstawy wychowania; intencjonalność działania wychowawczego; manipulacja jako sposób wywierania wpływu, forma przemocy i zjawisko społeczne; pedagogika humanistyczna i jej antropologiczne fundamenty oraz współczesne teorie i ideologie wychowania. Najważniejsze publikacje: Wychowanie a manipulacja (Kraków 2006), Nauczyciel w krajach postsocjalistycznych jako sprawca i ofiara manipulacji. Studium teoretyczno-empiryczne (red., Łódź 2010), Problem intencjonalności działania wychowawczego. Studium teoretyczne (Łódź 2014). Adres do korespondencji: Wydział Nauk o Wychowaniu UŁ, Katedra Teorii Wychowania, Zakład Teorii Kształcenia i Wychowania.Adres e-mailowy: alina_wrobel@ tlen.pl. 